\title{
THE INFLUENCE OF AN AMERICAN EDUCATOR (JOHN DEWEY) ON THE TURKISH EDUCATIONAL SYSTEM
}

BAHRİ ATA

\section{ABSTRACT}

This paper, discusses the influence of John Dewey's visit to Turkey, his report on the Turkish educational system and the Turkish educators by using especially the Turkish newspapers of that period. Consequently, invitation of Dewey presented as an indication of the desire of Atatürk for the establishment of democratic culture through education.

\section{KEYWORDS} Reforms.

Turkish Education System; John Dewey; Education; Republican 


\section{Introduction}

The invitation of the American educator and philosopher John Dewey (1859-1952) to Turkey by Mustafa Kemal (Atatürk) in 1924 was certainly the turning point between Turkey and the United States' relationship in terms of Turkish educational system. He was invited to Turkey to make his proposals to establish a democratic culture by the way of public school; to democratize the education of children; and to train the "army of teachers" in accordance with the democratic principles.

There are numerous studies in both Turkey and abroad, concerning the influence of Dewey's report on the newly emerged 'Turkish Republic. For example, in Turkey, Hüseyin Bal evaluated the influence of the Dewey report on the Turkish educational system in an excellent manner. ${ }^{1}$ Similarly, Büyükdüvenci, Biesta, Miedema and Wolf-Gazo showed that Dewey's report had a great impact on the Turkish educational practice. ${ }^{2}$ On the other hand, Büyükdüvenci particularly emphasized the negative influence of Dewey's pragmatism on Turkey.

Unlike other works, this paper will tackle the question of whether the Dewey's report reflects the views of Turkish authorities. Following questions will be answered in this context; 1) How did the Turkish educators discover John Dewey and his educational ideas and how Dewey was invited to Turkey? 2) What were the main points of the interviews with Dewey in the Turkish newspapers of that period? 3)To what degree the Dewey report was applied to the Turkish Educational System? Did this report reflect the Turkish educators' views? 4) How long have the tradition of John Dewey's pragmatism continued in Turkey?

\footnotetext{
${ }^{1}$ Hüseyin Bal, 1924 Raporunun Türk Eğitimine Etkisi ve J. Dewey'nin Eğitim Felsefesi, İstanbul, Aydınlar Matbaası, 1991.

2Sabri Büyükdüvenci, "John Dewey's Impact on Turkish Education", Studies in Philosophy and Education, Vol. 13, 1995, pp.393-400; Gert J.J Biesta \& Siebren Miedema, "Dewey in Europe: A Case Study on the International Dimensions of the Turn-of-the-Century Educational Reform", American Journal of Education, Vol. 105, 1996, pp. 1-26; Ernest Wolf-Gazo, "John Dewey in Turkey: A Educational Mission", Journal of American Studies of Turkey, Vol. 3, 1996, pp. 15-42.
} 


\section{The Discovery of John Dewey by the Turkish Educators and His Invitation to Turkey}

During the first decade of the $20^{\text {th }}$ century, Dewey's ideas became known abroad through his books and through the activities of such men as Georg Kerschensteiner in Germany, Edouard Claparède in Switzerland, Georges Bertier in France and J. J. Findlay in England. ${ }^{3}$ The Turkish educators were also acquainted with his ideas through their European colleagues. For instance, the journal article of Kazım Nami (Duru) on the educational system of John Dewey, that appeared in the Tanin, dated 16 August, 1924, was based on the views of Claparède. ${ }^{4}$ It seems that even Mustafa Rahmi (Balaban) used Claparede's view for Dewey in his book, Gazi Paşa Hazretlerinin Maarif Umdeleri (1923). ${ }^{5}$ Nafi Atuf (Kansu) in his Pedagoji Tarihi underlined the Speech of Kerschensteiner, including his opinion on John Dewey's writing in 1908.

Even in the United States, Dewey's impact was not massively felt until the publication of Democracy and Education in 1916 and the formation of the Progressive Education Association in $1919 .^{6}$ The decade of the American 1920s was called the decade of the Progressive Movement in Education. Yet Dewey's influence in the promotion of progressive education cannot be confined to the American shores. Indeed, it is during the 1920 s that Dewey move from the American education to truly one of international stature.

The discovery of Dewey by the Turkish educators at the early years of new Republic was not coincidental. As a godfather of progressives, Dewey advocated that the objective of education was to use schools to shape the social order. Atatürk and the staff

${ }^{3}$ S. J. Curtis \& M. E. A. Boultwood, A Short History of Educational Ideas, London, University Tutorial Press, 1966, p. 467.

${ }^{4}$ K. N. Duru, "Profesör John Dewey'nin Terbiye Sistemi", Tanin, 16 August 1924. Later on, Kazım Nami published these articles in his Terbiyevi Yazılar, İstanbul, Kanaat Kütüphanesi,1931, pp. 1-8.

${ }^{5}$ M. R. Balaban, Gazi Hazretlerinin Eğitim Umdesi: Asri Terbiye ve Maarif, 1923. And also See Seçil Akgün \& Murat Uluğtekin, "Misak-1 Maarif", Atatürk Yolu, Vol. 2 (3), 1989, pp. 285-349.

6J. R. Burnett, "Whatever Happened to John Dewey", Teachers College Record, Winter 1979, No. 2, p. 193. 
of Republic, too, wanted to use the school in order to give democratic and modern character to the Turkish society.

In the journal of Hakimiyet- $i$ Milliye, dated 11 May 1923, Mustafa Rahmi (Balaban) wrote the series of article on the educational principles of Gazi Mustafa Kemal Pasha. In these articles, Mustafa Rahmi tried to show philosophical origins of the "Speech" (Nutuk) of Gazi Mustafa Kemal on the aims of education in Turkish Republic, and also the Charter of Education (Maarif Misakl), declared by İsmail Safa (Özler) who was the Minister of Education. Mustafa Rahmi based the educational view of Mustafa Kemal Atatürk on the ground of John Dewey philosophy. Furthermore, Dewey's books such as Children and Society and School and Society were translated to Turkish by Mustafa Rahmi (Balaban) and Avni (Başman) before his arrival to Turkey. In 1923, he was invited by a letter of İsmail Safa, who was the Minister of Education. One year later, Dewey accepted the invitation of Turkish authorities.

According to the report, written by John Dewey, this journey was realized by the assistance of Charles R. Crane, ${ }^{7}$ one of those who wrote King-Crane Commission Report, dated 28 August, 1919. On June 1919, American President Wilson had sent an American Team, the King-Crane Commission, for six weeks from June to July to study the situation of the people of the area that later became Syria, Lebanon, Jordan and Palestine. In this report, there were sentences about the imperative necessity of education for the citizens of a democratic state, the development of a sound national spirit and the help of a national system of education in countries like Turkey and Syria.

In fact, the friendship of John Dewey with Charles R. Crane went back to 1907 's, because it can be seen that John Dewey appreciated him at the foreword of his School and Society in its publication of 1907. It can be even said that Dewey's earlier journey to China was realized by the help of Charles Crane who

\footnotetext{
${ }^{7}$ Charles R. Crane was born at Chicago, in 1858 . He was engaged in the manufacturing business in that city for more than a quarter of a century. He was a member of President Wilson's Special Diplomatic Commission to Russia in 1917, and a member of the American Section of the Peace Conference Inter-Allied Commission on Mandates in Turkey in 1919.
} 
was American Ambassador to China from May 1920, to June 1921.

\section{The Interviews with Dewey in the Turkish Newspapers}

It is easy to follow the program of Dewey's journey by using Turkish journals, such as Akşam, Cumhuriyet, Hakimiyet-i Milliye, Tanin, Vakit, Ikdam, Son Telgraf, as they gave great importance about Dewey and his educational ideas. Before his arrival to Turkey, certain discussions also occurred about foreign specialists and their roles in the journals of 1924.

For example, in Akşam, dated 20 June 1924, İsmayıl Hakk1 (Baltacığlu), Turkish educator and Rector of Darülfünun, advocated that Dewey was an pedagog-philosopher and the Turks needed an organizator such as Jules Ferry. ${ }^{8}$ But after his conversation with Dewey on the philosophy of pragmatism, the impact of American education on Europe, the school of Dr. Decroly, the problem of laicism and the reform of Darülfünun, İsmayil Hakk1 tried to correct his mistake by another article in Akşam, dated 25 July.

Dewey and his wife came to Turkey from Vienna by the Orient Express on 19 July 1924. Dewey took the first information about the Turkish Educational System in İstanbul from Fuat Köprülü, who was the undersecretary of Ministry of Education and preparing the budget of the Ministry for 1925 and İsmayıl Hakkı, the Rector of Darülfünun. Unfortunately, Dewey's journey overlapped the summer vacation of the schools in Turkey so he was not able to see the teacher-student relations and classroom atmosphere in Turkey. He tried to make inference from the situations of school buildings and its laboratories and teaching materials. Dewey gave great attention to the modern teaching materials like cinema machine and telephones in Galatasaray High School. But on the other hand, his journey ran into the Congress of Darulmuallimin and Darülmuallimat Graduates so that the Turkish teachers were able to reflect their economic problems to Dewey. On-31 July 1924, he talked with over 200 Turkish teachers at the drawing room of Darülmuallimin. In his opening speech, in the

${ }^{8}$ M. Ergün, Atatürk Devri Türk Eğitimi, Ankara, Ocak Yayınevi 1997, p.136. 
name of the graduate teachers, Mr. Şefik said that the arrival of John Dewey who gained great fame all over the world to Turkey would awaken the feeling of reliance to Turkish youth. ${ }^{9}$

On 9 August 1924, in the Conference Hall of Darülmuallimin, including 400 teachers, the Graduate Association performed a show in the honour of Dewey. The wall of stage was decorated with Turkish and the American flags. The Turkish folk dances were performed. Moliere's "Forced Wedding" was put on the stage and some rare piece of Dede Efendi was played. ${ }^{10}$

The main question of Turkish journalists to Dewey was what sort of education should be applied in the democratic system. In Son Telgraf and Ileri dated 16 August 1924, the letter of Dewey about the aim of his journey can be seen. In this letter, he stated his appreciation of the fact that the Turkish teachers had a high ideal because they resembled themselves to the "army" which struggles for the sake of science and progress, as it was expressed in the March issue of Darülmuallimin. He emphasized that there were no general programs and methods which can be applied to every and each country. However, the principles of education especially for democratic societies were the same. ${ }^{11}$ These were to develop the individual enterprise and the individual capability. And also he stressed that Turkey should not imitate any country, but should make use of their experiences by sending students and teachers to abroad.

In Ankara, Dewey joined the congress of Union of Teachers, which began on 22 August. At the feast of the Union of Teachers in the honour of Dewey, he met with Atatürk who talked with him for a long time. ${ }^{12}$ In his statement in Cumhuriyet and Hakimiyet- $i$ Milliye dated 24 August 1924, he emphasized that he came to Turkey not to take a duty as a consultant, but to make scientific research by the encouragement of Mr. Crane. He stressed that the connection of education which was given at school and life, especially village life should be provided. The curriculum of the

\footnotetext{
${ }^{9}$ Son Telgraf, 1 August 1924.

${ }^{10}$ Son Havadis, 10 August 1924.

${ }^{11}$ M. Zekeriya, "Dewey Ne Yapacak?" Cumhuriyet, 19 August 1924.

${ }^{12}$ E. B. Şapolyo, "Atatürk ve Maarif Misakı", Türk Kültürü, Vol. 40, 1966, p. 385.
} 
subject matters in the school should be changed due to the local environment. According to Dewey, the responsibility for the training of children as enterprising for democratic state should be provided by teachers. He emphasized that the principles of educational system should be determined. They were not changeable according to the ministers of education. After a short time, on 6 September 1924, the principles of education for Turkey was declared by Vasıf (Çınar) who was the minister of education at the time.

On 7 September 1924, he visited the historical places in Bursa. He concluded his journey in Turkey on 18 September 1924 , after a 10 days stay in İstanbul. He gathered the data mostly interviews with ministerial officials, teachers and journalists. He stated his observations in the Turkish journals before writing his final report.

\section{The Application of the Dewey Report to the Turkish Educational System}

The Ministry of Education asked Dewey for the preliminary report immediately to put his proposals to the National Budget on education for 1925 and Dewey submitted the main report to Turkish government. The Turkish translation of his report was published in Maarif Vekaleti Mecmuası in 1925. ${ }^{13}$

Dewey classified his proposals into seven categories. These were, "Program", "Organization of the Ministry of Public Instruction", "Training and Treatment of Teachers", "School System", "Health and Hygiene", "School Discipline" and "Miscellaneous". ${ }^{14}$

13 "Profesör John Dewey'nin Raporları", Maarif Vekaleti Mecmuası, 1 March 1925, No. 1. Its Turkish translation was published several times. In 1939, during the time of Hasan Ali Yücel, Minister of Education, the Dewey report was republished.

${ }^{14}$ John Dewey, The John Dewey Report, Ankara, M.E.B. Talim ve Terbiye Dairesi, Test ve Araştırma Bürosu, 1960. 
Mustafa Necati (1893-1929), Minister of Education between 1925 and 1929, put Dewey's ideas into practice. ${ }^{15}$ These applications can be followed by the issues of journals such as Maarif Vekaleti Mecmuast, Terbiye and Hayat. As he proposed, Mustafa Necati established the Department of Instruction and Education (Talim ve Terbiye Dairesi) in 1926. Mehmet Emin Erişirgil became its president. ${ }^{16}$ In 1926, the establishment of Gazi Teachers Training Institute to train teachers for secondary school was inspired by the Dewey's report. Finally, the Bureau of School Architecture was established in 1927 and Prof. Dr. Ernest Egli became the chief of this bureau. ${ }^{17}$

Dewey proposed that, it is dangerous to imitate the educational system of other nations in exact form and the formation of Turkish system should synthesize the good parts of various countries' systems. At this time, in Maarif Vekaleti Mecmuast, there were many articles describing the educational systems of countries such as France, Germany, Russia, Bulgaria, Denmark, Italy, Japan and Czechoslovakia.

For Dewey, the most urgent problem of Turkey was teachers and their situations. As the heart of education was the teacher, the reform should begin by improving the position of teachers. Those days when Dewey came to Turkey, Turkish teachers were struggling to make a living. One of the outstanding subject of Congress of Teachers Union was the low salary of teachers. Dewey listened to teacher's complaints about their salaries and then mentioned this problem in his report.

According to the report, students should have an interactive relationship with village and their environments. High schools should prepare the students for the profession. The individual enterprise should be gained at the elementary school. Children should be active and enterprising in the democratic society. Under the light of these proposals, the reforms of curriculum of the primary school began in 1926, two years after Dewey was invited

${ }^{15}$ Ergün, Atatürk Devri Türk Eğitimi, p. 139.

${ }^{16}$ O. Kafadar, "Türk Eğitim Sisteminde Pragmatik Yönelişler ve Mehmet Emin Erişirgil", Türkiye Eğitim Felsefesi Kongresi, Van, Yüzüncü Yııl Üniversitesi, 1994, p. 176.

${ }^{17} \mathrm{Bal}, 1924$ Raporunun Türk Ĕgitimine Etkisi, p. 69. 
by the Turkish government to build up a modern educational system. In his report, he urged that the content of studies should be modified in different sections of the country to adapt to local conditions and needs. ${ }^{18}$ In accordance with the progressive philosophy, a new course, Life Studies (Hayat Bilgisi) was put into the curriculum of elementary schools for first three grades. ${ }^{19}$

According to Dewey, children should be rescued from becoming the slave of books. But Turkish authorities did not apply this idea because most of the population in Turkey was illiterate. However, in Atatürk's time, in 1930's, the text books of science education for the secondary schools was translated from American text books. The units of this books were written according to the problem-focused approach. As Dewey proposed, mobile libraries and exhibitions were established. The Ministry of Education sent librarians to abroad to study library science.

Dewey stressed that the schools should be made the centers of community life, especially in the rural districts. The question of adapting the schools to local conditions was reiterated in Turkey. Village Institutes (Köy Enstitüleri) seem to be designed to fulfill John Dewey's idea of combining work and education. Graduates were expected to be both school teachers and community leaders at the same time. Students actually built their own schools, homes, barracks, work places etc., and learned by doing and living together. ${ }^{20}$

The Dewey's report reflects not just his educational ideas, but the ideas of Turkish educators whom Dewey talked with during his journey. Indeed, it is really difficult to separate the views of Turkish educators who were under the influence of European education, from that of Dewey. The Turkish educators knew very well the ideas of European educators such as Pestalozzi, Froebel and Montessori whose ideas gained much acceptance throughout the US. In his report, Dewey mentioned the model of Danish public school for agricultural education. Indeed, in 1922, İhsan

\footnotetext{
${ }^{18}$ A. M. Kazamias, Education and The Quest For Modernity in Turkey, Chicago, The University of Chicago Press, 1969, p. 141.

${ }^{19}$ Kafadar, "Türk Eğitim Sisteminde Pragmatik Yönelişler", p. 178.

${ }^{20} \mathrm{~B}$. Güvenç, "History of Turkish Education", Education and Science, Vol. 22 (108), Special Issue, 1998, p. 56.
} 
Sungu gave a conference on Danish Public Schools in Darülmuallimin. He tried to indicate Danish case on the subject of providing the welfare of peasants as a model for Turkey. ${ }^{21}$ Interestingly enough, on the other hand, İhsan Sungu made an effort to spread the educational ideas of Dewey through his translations. Dewey proposed the application of project methods in the schools. With his article on the project method in Terbiye in 1930, İhsan Sungu tried to spread this new method to all the Turkish schools. ${ }^{22}$

In 1923, at the meeting of the second Scientific Commission, Ziya Gökalp touched on the education of village children and the opening of vocational schools. ${ }^{23}$ Because of the illness of Ziya Gökalp in $1924^{24}$, Dewey did not meet him; but Gökalp's ideas began to flourish among the Turkish educators. Especially, the idea of training teachers for village went back to the second constitutional period.

\section{The Tradition of John Dewey's Pragmatism in Turkey}

Unlike the other foreign specialist who gave a report to the Ministry of Education at the early years of Turkish Republic, Dewey has a distinct place for Turkish educators. Unfortunately, due to the social and political conditions, some of the proposals, concerning the democratic education were not applied.

In the Turkish journals of 1925 , it is possible to see the advertisement of a special school which declared that its aim was to bring up men of business and life by applying the teaching methods of progressive schools in America. ${ }^{25}$

After Dewey left Turkey, series of articles and a book on the A.merican education system appeared in the Turkish language. In 1925, Abdullah Cevdet translated Dr. Ömer Buyse's Méthodes

${ }^{2 !}$ M. R. Öymen, "Muallim Mektepleri ve Terbiye Hareketleri", Yeni Bilgi, Vol. I (10), 1948, p. 18.

22i. Sungu, "Proje Usulu", Terbiye, No. 3, 1930, pp. 181-195.

${ }^{23}$ Şapolyo, "Atatürk ve Maarif Misakı", p. 384.

${ }^{2}$ Ziya Gökalp died on 25 October 1924.

${ }^{25}$ Cumhuriyet, 23 August 1925, p.5. 
Américaines d'Education into Turkish. ${ }^{26}$ The Turkish intellectuals like Abdullah Cevdet tried to strive the mentality transformation of the Turkish people through this kind of books.

On 28 October 1949, it seems that the Turkish educators even organize a symposium for the Anniversary of Dewey's $90^{\text {th }}$ birthday in Turkey. ${ }^{27}$ In this symposium, Fuat Gündüzalp and Nevzat Ayas considered the influence of Dewey on Turkish education. ${ }^{28}$ Interestingly enough, some of the Turkish teachers were in contact him through letters.

However, despite all the above mentioned activities, the Turkish educational system was not able to rescue itself from the traditional school system, imported from France. ${ }^{29}$

Until 1960's, his long term impact was provided through his books, one of must-readings in the School of Elementary School Teacher Training in Turkey. His educational ideas were spread among the Turkish teachers through his books and his articles, translated in to Turkish. In the US, in 1970's Dewey's educational philosophy had become a target for those who seek a scapegoat for the decline in the American education. Parallel to the US, the Turkish educators, too, put the books of Dewey on the shelf.

In the book review of Democracy and Education in 1930, Mehmet Saffet regarded the pragmatism as the philosophy of democratic society. ${ }^{30}$ In fact, it seems that there are two kind of pragmatism; German interpretation of pragmatism that went back to Hegelian Philosophy, and American interpretation of pragmatism. In 1920's, the authorities in the Ministry of Education accepted the German interpretation of pragmatism including patriotism and hero-worship. On the other hand, American

${ }^{26}$ Ömer Buyse, Amerika Terbiye Usulleri (trans. Abdullah Cevdet), İstanbul, Matbaa-i Amire, 1925.

271. Yasa, "J. Dewey'nin 90. Yıl Dönümü Dolayısıyla", Ilköğretim, No. 283,1949, p. 369.

${ }^{28}$ N. Ayas, "John Dewey'nin Raporu Hakkında", Ilköğretim, No. 284-286, 1949.

${ }^{29}$ O. Kafadar, "Türk Eğitim Sisteminde Pragmatik Yönelişler", p. 183.

${ }^{30}$ Mehmet Saffet, "Demokrasi ve Terbiye", Hayat, No. 4, 1930, pp. 335340 . 
interpretation of pragmatism includes problem solving, reflective and scientific thinking.

In 1990's, like the Americans, the Turkish educators rediscovered Dewey and his report. As Güçlüol said, the period of reports in Turkey gave its place to the period of scientific researches, but some problems in the Turkish education, stated by Dewey are still being felt. According to Güçlüol, the Dewey report should be re-examined by those concerns. ${ }^{31}$

\section{Conclusion}

The invitation of Dewey to, and his report on Turkey can be seen as an indication of the desire of Atatürk for the establishment of democratic culture through education. Dewey paved the way for other American educators such as Miss Berly Parker and V. Wofford.

The Dewey Report itself should not be taken as a prescription, written for Turkish education and the Turkish authorities who put some of them into action as passive receivers. On the contrary, the interaction between Dewey and Turkish authorities was reciprocal. Some of the proposals of Dewey which were stated in his report were applied to the Turkish educational system, as they were at the same time the ideas of Turkish authorities, who wished to legitimaze their applications on the ground of Dewey's report. This situation can be seen clearly in the case of village institutes. In fact, it can be argued that the others, which were not put into action, really belonged to John Dewey. The real success of Dewey was to grasp the problems of Turkey in three months.

${ }^{31}$ K. Güçlüol, "John Dewey'den Bugüne Milli Eğitimimiz", Yeni Türkiye, No. 7, 1996, p. 456. 